\title{
Do alterations in gene expressions influence tumorigenesis in the transmissible
} venereal tumor in dogs?

\author{
Haline Ballestero Fêo ${ }^{1^{*}}$ Luis Mauricio Montoya Flórez ${ }^{1,2}$ Ricardo Seiti Yamatogi $^{\text {(DD }}$ \\ Anderson do Prado Duzanski ${ }^{1,6}$ João Pessoa Araújo Junior ${ }^{4}[$ \\ Rogerio Antonio de Oliveira ${ }^{5}$ Noeme Sousa Rocha ${ }^{1}$ (D)
}

\begin{abstract}
${ }^{1}$ Departamento de Clínica Veterinária, Faculdade de Medicina Veterinária e Zootecnica, Universidade Estadual Paulista (UNESP), 18618-681, Botucatu, SP, Brasil. E-mail: halinebf@hotmail.com. "Corresponding author.

${ }^{2}$ Grupo de Pesquisa em Patologia Veterinária, Faculdade de Medicina Veterinária, Universidad Nacional de Colombia (UNAL), Bogotá, Colômbia.

${ }^{3}$ Departamento de Veterinária, Universidade Federal de Viçosa (UFV), Viçosa, MG, Brasil.

${ }^{4}$ Departamento de Microbiologia e Imunologia, Instituto de Biociências, Laboratório de Virologia, Universidade Estadual Paulista (UNESP), Botucatu SP, Brasil.

${ }^{5}$ Departamento de Bioestatística, Instituto de Biociências, Universidade Estadual Paulista (UNESP), Botucatu, SP, Brasil.

${ }^{6}$ Departamento de Patologia, Faculdade de Medicina de Botucatu, Universidade Estadual Paulista (UNESP), Botucatu, SP, Brasil.
\end{abstract}

ABSTRACT: Canine transmissible venereal tumor (CTVT) is a transmissible neoplasm, which spreads naturally between dogs through the halogenic transfer of tumor cells, mainly during coitus. It is the oldest known tumoral lineage in nature and reports on gene mutations have been extended. Also, this tumor shares several genetic mutations with some cancers in humans, among them lung carcinomas, melanoma, prostate, breast, among other cancers. Thus, expression of tumor suppressor genes such as TP53, P21, and apoptosis-related genes such as BAX, BCL2 , and $B C L-x L$, both in vivo and in vitro (primary cell culture) were quantified. In the present study, the comparison of gene expression, the TP53 gene, in most cases, was shown to be high in the majority of tissues (65\%) and primary cell culture (100\%), while BCL-2, BCL-xL, and $B A X$ presented variation among the animals analyzed. Moreover, in these situations, the results suggested that the apoptotic regulation of these genes did not occur for TP53. The P21 gene was shown to be mostly normal (70\%); although, absence (6\%) and underexpressions (24\%) were also observed. Statistical analysis of the BCL-xL gene demonstrated significant differences between the tissues of the animals when compared to the cell cultures; however, to the other genes, no statistical difference was observed between the groups. Preliminarily, the results suggested the presence of alterations in the gene expressions of the TP53, P21, BAX,BCL-2 and BCL-xL leading to loss of function in these genes, which affect the tumorigenesis of CTVT.

Key words: cancer, apoptosis, genetic alterations, cell cultures.

Alterações nas expressões gênicas influenciam na tumorigênese no tumor venéreo transmissível em cães?

RESUMO: O tumor venéreo transmissível canino (TVTC) se trata de uma neoplasia transmissivel, que se propaga naturalmente entre os cães pela transferência halogênica de células tumorais, principalmente, durante o coito. É a mais antiga linhagem tumoral conhecida na natureza e relatos sobre mutações gênicas vêm sendo ampliadas. Além disso, este tumor compartilha uma série de mutações genéticas com alguns cânceres em seres humanos, dentre eles, carcinomas de pulmão, melanoma, próstata, mama, entre outros tipos de câncer. Assim, quantificouse a expressão de genes supressores de tumores, como TP53, P21 e genes relacionados à apoptose, como BAX, BCL-2 e BCL-xL, tanto in vivo quanto in vitro (cultura celular primária). No presente estudo, na comparação das expressões gênicas, o gene TP53 se mostrou elevado na maioria dos casos em tecidos (65\%) e em cultura celular primária (100\%), enquanto BCL-2, BCL-xL e BAX apresentaram-se variáveis entre os animais analisados. Ademais, nessas situações os resultados sugerem que não ocorreu regulação apoptótica desses genes pelo TP53. O gene P21 mostrou-se, em sua maioria, normal (70\%), embora a ausência (6\%) e subexpressões (24\%) também tenham sido observadas. $A$ análise estatística do gene BCL-xL demonstrou diferenças significativas entre os tecidos dos animais, quando comparadas às culturas celulares, entretanto, para os demais genes, não foi observada diferença estatística entre os grupos. Preliminarmente, os resultados sugerem a presença de alterações nas expressões gênicas dos genes TP53, P21, BAX, BCL-2 e BCL-xL, levando a perda de função desses genes, os quais afetam a tumorigênese do CTVT.

Palavras-chave: câncer, apoptose, alterações genéticas, Culturas celulares.

\section{INTRODUCTION}

The Canine transmissible venereal tumor (CTVT) arouses great interest in oncology researchers due to several characteristics, among them its controversial origin (MUKARATIRWA et al., 2003; FLÓREZ et al., 2016; DUZANSKI et al., 2017), questionable spontaneous regression 
(TINUCCI-COSTA, 2009; ÖSALP et al., 2012), and resistance to chemotherapy (BOSCOS, 1999), as well as being a research model for comparative oncology (BELOV, 2012).

CTVT cells have the particularity of implanting in the mucous membranes, when they lose integrity (STOCKMANN et al., 2011), in a way that the tumor is established, proliferates, and may even develop metastases (OJEDA et al., 2018). Once established, the clinical manifestation may range from a solitary formation to multiple lobes, preferably on the external genitalia (SANTOS et al., 2005).

Characterization of the gene expression profile in tumors has been a powerful approach for the delineation of the molecular pathways and altered cellular processes in the neoplasias (MURCHISON et al., 2014; DECKER et al., 2015). Regarding CTVT, reports on gene mutations have been increasing (MURGIA et al., 2006; FONSECA et al., 2012; MURCHISON et al., 2014)

The TP53 gene is a key component of the cell cycle and one of the most studied tumor suppressor genes. This gene is inactivated, commonly by mutation, in more than half of the cancers in humans (KUSEWITT, 2013). The 553 protein encoded by this gene can positively regulate p21 expression, which induces the expression of repair genes against DNA damage, as well as having an active role in cell cycle arrest (ABBAS \& DUTTA, 2009).

In addition to $\mathrm{p} 21, T P 53$ also participates in the regulation of Bcl-2 family members. The Bcl-2 family is a group of proteins that induce or inhibit cell death by apoptosis. Some members of the Bcl-2 family, including Bcl-2 and Bcl-xL, are antiapoptotic regulators that inhibit apoptosis, preventing the release of cytochrome $\mathrm{c}$ from mitochondria. Other members of this family, Bax, Bid and Bak, are proapoptotic proteins (STOCKMANN et al., 2011).

To date, in CTVT, there have been no reports on $B C L-x L$ expression; however, $B C L-2$ expression has been identified, as well as mutations in TP53 (CHOI \& KIM, 2002; VÁZQUEZ-MOTA et al., 2008; ALZATE et al., 2009; STOCKMANN et al., 2011; FLÓREZ et al., 2017). However; although, there is evidence of mutations of the TP53 gene in CTVT, the ability of this mutation to cause functional changes in the protein, as well as in the tumor evolution remains unknown (VÁZQUEZ-MOTA et al., 2008).

According to STOCKMANN et al. (2011) overexpression of $\mathrm{Bcl}-2$ occurs independent of the stage of tumor development and this overexpression would promote the acquisition of functions in the tumor, which are associated with progression and survival. Similarly,
AMARAL et al. (2011) showed that CTVTs with a lower degree of aggressiveness have a high apoptotic index and may present a better prognosis.

Due to the importance of better understanding the evolution and biological behavior of CTVT, this study aimed to observe if there are differences in the expression of tumor suppressor genes (TP53 and P21) and genes related to the apoptosis process $(B C L-2, B C L-x L$, and $B A X)$ in vivo and in vitro (primary cell culture) in CTVT.

\section{MATERIALS AND METHODS}

\section{Tumor collection}

Once the diagnosis of CTVT was confirmed by cytological and histological analysis, and after anesthesia of the animal with total asepsis at the location, 2 replicates of the tumor samples were collected through incisional biopsy of fragments of approximately $1 \mathrm{~cm}^{3}$. The clinical data of the animals with CTVT submitted to the present study like sex, age (years), breed and tumors' location are specified in table 1 .

The RNA was isolated from 17 tumor tissues and 3 cell cultures from tumor tissues. The sample size followed the criteria established by GASPAR et al., (2009; 2010), DOHOO et al., (2009) e STOCKMAN et al., (2011). Samples were stored in Phosphate Buffered Saline (PBS) $\mathrm{pH} \mathrm{7.4,} \mathrm{and}$ RNAlater (Qiagen) in the Department of Pathology, until the material was processed. The relative concentration of the studied genes was normalized according to LARIONOV et al. (2005) through the most stable endogenous control among the three endogenous tested (RPS5, RPS19, and ACTB) according to BRINKHOF et al. (2006) and all reactions were performed in duplicate.

Tissue samples and insulations of CTVT cultures had the number of chromosomes analyzed at the Animal Genetics Laboratory of the Biosciences Institute (FLÓREZ et al., 2016).

\section{Primary culture of CTVT}

Insulations of CTVT cultures from the tumor collections (Table 1) were performed according to the protocol described by HSIAO et al. (2008) and FLÓREZ et al (2016). For this purpose, tumor fragments were placed in PBS pH 7.4 and taken to the In vitro Fertilization and Cell Culture Laboratory of the Animal Reproduction and Veterinary Radiology Department of Veterinary Hospital.

Subsequently, the fragments were transferred to trypsin solution (TrypLESelect Invitrogen) at $37.5{ }^{\circ} \mathrm{C}$ for $40 \mathrm{~min}$ in a magnetic 
Table 1 - Clinical data of patients with CTVT attended at the Veterinary Hospital.

\begin{tabular}{|c|c|c|c|c|c|c|c|}
\hline Animal & Sex & Age (years) & Breed & Location & Classification & Stage & Treatment Response \\
\hline 1 & M & 9 & Mixed & penis & $\mathrm{P}$ & Initial Regression & $\mathrm{R}$ \\
\hline 2 & $\mathrm{~F}$ & 9 & Dachshund & vagina & $\mathrm{P}$ & Progression & $\mathrm{CR}$ \\
\hline $3^{*}$ & M & 7 & Mixed & penis & $\mathrm{P}$ & Regression & $\mathrm{CR}$ \\
\hline 4 & M & 9 & Mixed & penis & $\mathrm{P}$ & Regression & $\mathrm{CR}$ \\
\hline 5 & $\mathrm{M}$ & - & Mixed & skin - penis & $\mathrm{P}$ & Progression & $\mathrm{CR}$ \\
\hline 6 & $\mathrm{M}$ & 10 & Mixed & penis & $\mathrm{P}$ & Progression & $\mathrm{CR}$ \\
\hline 7 & $\mathrm{M}$ & - & Mixed & penis & $\mathrm{P}$ & Progression & CR \\
\hline $8^{*}$ & $\mathrm{~F}$ & 10 & Mixed & vagina & $\mathrm{P}$ & Progression & PR \\
\hline $9^{*}$ & M & 5 & Mixed & penis & $\mathrm{P}$ & Initial Regression & PR \\
\hline 10 & M & 6 & Mixed & penis & $\mathrm{P}$ & Progression & $\mathrm{CR}$ \\
\hline 11 & M & - & Mixed & penis & $\mathrm{P}$ & Progression & $\mathrm{R}$ \\
\hline 12 & M & 8 & Poodle & oral cavity & $\mathrm{P}$ & Progression & $\mathrm{CR}$ \\
\hline 13 & M & 10 & Mixed & penis & $\mathrm{P}$ & Progression & $\mathrm{CR}$ \\
\hline 14 & M & 10 & Mixed & penis & $\mathrm{P}$ & Progression & $\mathrm{CR}$ \\
\hline 15 & M & 16 & Mixed & skin - penis & $\mathrm{P}$ & Progression & $\mathrm{CR}$ \\
\hline 16 & M & - & Bull Terrier & penis & $\mathrm{P}$ & Progression & $\mathrm{CR}$ \\
\hline 17 & M & - & Mixed & penis & $\mathrm{P}$ & Progression & $\mathrm{CR}$ \\
\hline
\end{tabular}

${ }^{*}$ Tumor samples that were used to perform isolations for cell cultures.

$\mathrm{M}=$ male; $\mathrm{F}=$ female; $-=$ not specified by owner; Mixed $=$ mixed breed; $\mathrm{P}=$ plasmacytoid; $\mathrm{R}=$ resistant; $\mathrm{PR}=$ partial response; $\mathrm{CR}=$ complete response.

homogenizer. The solution was centrifuged $(820 \mathrm{~g}$, $4{ }^{\circ} \mathrm{C}, 25 \mathrm{~min}$ ), and the pellet resuspended and packed in $25 \mathrm{~cm}^{2}$ flasks (Sarstedt) with $5 \mathrm{~mL}$ of high glucose DMEM culture medium (Dulbecco's modified essential medium - Gibco), 10\% fetal bovine serum (FBS) (Gibco), and a combination of $100 \mathrm{U} / \mathrm{ml}$ penicillin, 100 $\mathrm{mg} / \mathrm{ml}$ streptomycin (Gibco), and $3 \mu \mathrm{g} / \mathrm{ml}$ amphotericin B (Gibco).

Samples were then incubated in a $5 \% \mathrm{CO}_{2}$ culture incubator, at $95 \%$ humidity and $37.5^{\circ} \mathrm{C}$. Cell viability and concentration were determined by the trypan blue exclusion test and the cells resuspended in complete medium (formulation above paragraph). In addition, in order to verify if the cells isolated were from the tumor (CTVT) belonged to the CTVT, samples were submitted to chromosome number analysis in the Laboratory of Animal Genetics of the Institute of Biosciences.

\section{Real-time reverse transcriptase polymerase chain reaction ( $R T-q P C R)$}

From the total of 17 tumor tissues and 3 isolations of CTVT cultures gene expression was obtained from a variable number of samples, depending on the gene analysed.
RNA extraction was performed with the RNeasy Mini kit (Qiagen) according to the manufacturer's instructions. After purification of the RNA, it was treated with RQ1 RNase-free DNase (Promega) for $30 \mathrm{~min}$ at $37^{\circ} \mathrm{C}$ to avoid false-positive results from genomic DNA amplification. The quality of RNA extracted was evaluated in $2 \%$ agarose gel stained with ethidium bromide in NanoVue (GE Healthcare) equipment, and the samples were subsequently stored at $-80{ }^{\circ} \mathrm{C}$.

For the cDNA synthesis, $1 \mu \mathrm{g}$ of RNA and the High Capacity kit (Applied Biosystems) were used. The reaction was performed with $6 \mu \mathrm{L}$ Random Primer (10x), $6 \mu \mathrm{L}$ RT buffer (10x), $2.5 \mu \mathrm{L}$ dNTPs (25x), $3 \mu \mathrm{L}$ Multiscribe $(50 \mathrm{U} / \mu \mathrm{L})$ and RNasefree water, according to the manufacturer's protocol. Subsequently, incubation was performed at $25^{\circ} \mathrm{C}$ for $10 \mathrm{~min}$ and at $37^{\circ} \mathrm{C}$ for 120 min with the automatic thermal cycler (ABI Prism 7500 FAST Sequence Detection System, Applied Biosystems). The samples remained at $4{ }^{\circ} \mathrm{C}$ until amplification by RT-qPCR.

For amplification of primer sequences (Table 2), SYBR Green and the universal PCR Master Mix (Promega) were used according to the manufacturer's instructions. The qPCR reaction 
Table 2 - Sequence of primers of the genes used in the RT-qPCR.

\begin{tabular}{|c|c|c|}
\hline Gene & Sense $\left(5^{\prime} \rightarrow 3^{\prime}\right)$ & Antisense $\left(3^{\prime} \rightarrow 5^{\prime}\right)$ \\
\hline RPS5 & GAGGCGTCAGGCTGTCGAT & AGCCAAATGGCCTGATTCAC \\
\hline RPS19 & GGGTCCTCCAAGCCCTAGAG & CGGCCCCCATCTTGGT \\
\hline ACTB & GGCATCCTGACCCTCAAGTA & СТTCTCCATGTCGTCCCAGT \\
\hline $\mathrm{TP} 3^{\mathrm{a}}$ & CGCAAAAGAAGAAGCCACTA & TCCACTCTGGGCATCCTT \\
\hline $\mathrm{P} 21^{\mathrm{a}}$ & ACCTCTCAGGGCCGAAAAC & TAGGGCTTCCTCTTGGAGAA \\
\hline BCL-2 ${ }^{b}$ & TGGATGACTGAGTAGCTGAA & GGCCTACTGACTTCACTTAT \\
\hline BCL-xL ${ }^{b}$ & GGCCTTTTTCTCCTTCGGTG & CTCTCGGCTGCTGCATTGTT \\
\hline $\mathrm{BAX}^{\mathrm{c}}$ & GGTTGTTGCCCTCCTCTACT & GTAAGCACTCCAGCCACAAA \\
\hline
\end{tabular}

${ }^{a}$ KLOPFLEISCH et al., 2009.

${ }^{\mathrm{b}}$ KLOPFLEISCH et al., 2010.

${ }^{c}$ SANO et al., 2005.

consisted of $4 \mu \mathrm{L}$ of the cDNA sample, $200 \mathrm{nM}$ of each primer, $10 \mu \mathrm{L}$ of GoTaq qPCR Master Mix (Promega), and nuclease-free water, with a final volume of $20 \mu \mathrm{L}$.

The reaction conditions for all genes were: initial denaturation at $95{ }^{\circ} \mathrm{C}$ for 2 minutes, followed by 40 cycles of amplification $\left(95{ }^{\circ} \mathrm{C}\right.$ for $15 \mathrm{~s}$ for denaturation, $60{ }^{\circ} \mathrm{C}$ for $1 \mathrm{~min}$ for annealing and extension) and the dissociation curve $\left(95{ }^{\circ} \mathrm{C}\right.$ for $15 \mathrm{~s}, 60{ }^{\circ} \mathrm{C}$ for $30 \mathrm{~s}$, and $95{ }^{\circ} \mathrm{C}$ for $15 \mathrm{~s}$ ). As a negative control, nuclease-free water was used. The relative standard curve for each gene was generated by serial dilutions of cDNA from a reference sample. The lowest dilution of the standard was considered as the relative value of 100 , followed by $1 / 10$ serial dilutions. The 3 points were 10,1 , and 0.1 .

The relative concentration of the studied genes was normalized according to LARIONOV et al. (2005) through the most stable endogenous control among the three endogenous tested (RPS5, RPS19, and ACTB) according to BRINKHOF et al. (2006). All reactions were performed in duplicate and the value of $\mathrm{QR}<0.5$ was considered as a reduction in the expression and $\mathrm{QR}>2.0$ as an increase in the expression.

\section{Statistical analysis}

For statistical analysis, non-parametric tests ofWilcoxon ( 2 independent samples) were used. Results of the gene expressions obtained from tissue were compared to the expression of the same genes obtained from in vitro assays. The medians for each group were compared and statistically significant differences were indicated by the acronym QR, considered when the test $\mathrm{P}$-value was below the significance level of $0.05(\mathrm{P}<$
0.05). Statistical analyses were performed in the SAS statistical program.

\section{RESULTS}

The RNA was isolated from 17 tumor tissues and 3 cell cultures from tumor tissues (Table 3). In agarose gel they presented good integrity of ribosomal RNA 18s and 28s. Cell culture of 3 samples from tumor tissues was also performed.

Analyzes of the TP53 gene revealed high expression in $65 \%$ of tissues $(\mathrm{QR}=2.7$ to 7.6$)$, except for $29 \%$ that lacked expression and one $6 \%$ that presented low expression $(\mathrm{QR}=0.2)$. The cultured cells also presented high expression for this gene $(100 \%)(\mathrm{QR}=2.6$ to 3.5$)$. For the gene encoding the p21 protein, $70 \%$ presented normal expression $(\mathrm{QR}=0.5$ to 1.4$)$, except for $30 \%$ of the samples, where $6 \%$ demonstrated an absence and the others were underexpressed $(24 \%)(\mathrm{QR}=0.2$ to 0.4$)$. The cells also presented normal expression $(67 \%)(\mathrm{QR}=$ 0.5 and 1.6$)$ and underexpression $(33 \%)(\mathrm{QR}=0.4)$. Statistical analyzes of TP53 and P21 genes did not demonstrate significant differences between tissues when compared to cell cultures $(\mathrm{P}>0.05)$.

For $B C L-2$, only $6 \%$ of the samples presented high expression $(\mathrm{QR}=2.3), 35 \%$ no expression, and $18 \%$ low expression $(\mathrm{QR}=0.44$ to 0.46$)$, the others were considered normal $(41 \%)$ $(\mathrm{QR}=0.5$ to 1.9$)$. In the culture, one sample presented overexpression $(33 \%)(\mathrm{QR}=2.5)$ and the others presented normal expression $(67 \%)(\mathrm{QR}=0.7$ and $0.8)$. Statistical analyzes of $B C L-2$ gene did not demonstrate significant differences between tissues and cell cultures $(\mathrm{P}>0.05)$. 
Table 3 - Numerical values (QR) for RT-qPCR analysis of TP53, P21, BCL-2, BCL- $x L$, and $B A X$ genes in tissue and cultured CTVT samples.

\begin{tabular}{|c|c|c|c|c|c|}
\hline Sample & TP53 & P21 & BCL-2 & BCL-xL & BAX \\
\hline $\mathrm{T} 1$ & 0 & 0.273 & 0 & 0.909 & 1.03 \\
\hline $\mathrm{T} 2$ & 0.215 & 0.353 & 0 & 0.012 & 0 \\
\hline $\mathrm{T} 3$ & 5.247 & 1.426 & 1.840 & 0 & 2.38 \\
\hline $\mathrm{T} 4$ & 0 & 0 & 0 & 0 & 0 \\
\hline $\mathrm{T} 5$ & 3.860 & 0.427 & 0.440 & 0.034 & 1.65 \\
\hline $\mathrm{T} 6$ & 0 & 0.586 & 0 & 0.029 & 0 \\
\hline $\mathrm{T} 7$ & 0 & 0.861 & 0 & 0.018 & 0 \\
\hline $\mathrm{T} 8$ & 2.940 & 0.901 & 0.440 & 0.026 & 1.29 \\
\hline T9 & 7.690 & 1.018 & 1.910 & 0.017 & 2.84 \\
\hline T10 & 3.250 & 0.511 & 0.460 & 0.021 & 2.00 \\
\hline T11 & 4.110 & 0.753 & 0.533 & 0.010 & 0.93 \\
\hline $\mathrm{T} 12$ & 0 & 0.748 & 0 & 0.005 & 0 \\
\hline $\mathrm{T} 13$ & 3.230 & 0.772 & 0.820 & 0.009 & 1.67 \\
\hline $\mathrm{T} 14$ & 6.630 & 0.594 & 1.040 & 0.318 & 2.59 \\
\hline $\mathrm{T} 15$ & 7.480 & 0.311 & 1.120 & 0.051 & 3.79 \\
\hline $\mathrm{T} 16$ & 4.720 & 0.837 & 2.320 & 0.003 & 3.11 \\
\hline $\mathrm{T} 17$ & 2.750 & 0.713 & 0.880 & 0.713 & 2.85 \\
\hline $\mathrm{C} 1$ & 3.500 & 0.560 & 0.890 & 0.780 & 0.80 \\
\hline $\mathrm{C} 2$ & 2.840 & 1.690 & 2.580 & 0.540 & 1.20 \\
\hline $\mathrm{C} 3$ & 2.690 & 0.460 & 0.770 & 0.180 & 0.89 \\
\hline
\end{tabular}

$\mathrm{T}=$ tissue; $\mathrm{C}=$ cell.

The gene $B C L-x L$ was normal in $12 \%$ of the samples $(\mathrm{QR}=0.7$ and 0.9$)$, underexpressed in $76 \%(0.005$ to 0.3$)$, and absent in other $12 \%$. In the culture, $33 \%$ presented underexpression $(\mathrm{QR}=$ 0.1 ) and normal expression in $67 \%(\mathrm{QR}=0.5$ and $0.7)$. $B A X$ was normal in $29 \%$ of the samples (QR $=0.9$ a 1.6), overexpressed in $42 \%(\mathrm{QR}=2.3 \mathrm{a}$ 3.7 ), and absent in other $29 \%$. The cultured cells presented normal expression for this gene (100\%) $(\mathrm{QR}=0.8$ a 1.2). Statistical analyzes of $B A X$ gene did not demonstrate significant differences between tissues and cell cultures, whereas $B C L$ $x L$ expression demonstrate significant differences in tissue samples in relation to samples from cell cultures $(\mathrm{P}<0.05)$ (Figure 1).

\section{DISCUSSION}

The TP53 gene revealed high expression in tissues and the cultured cells also presented high expression for this gene. Overexpression of this gene has been considered a marker of the presence of mutations in several types of cancers (MORO et al., 2010) and its expression has been linked to an unfavorable prognosis in lymphomas (VELDHOEN et al., 1998) and breast tumors (LEE et al., 2004).

However, in other types of tumors, variable behavior has been described mainly due to the functions that this gene exerts in the cellular micro-environment. TP53 encodes the protein p53, responsible for inducing cell death via apoptosis (SUI et al., 2011), besides participating in different phases of the cell cycle, such as in the G1-S phase through the transactivation of $\mathrm{p} 21$, and in the G2-M phase blocking the entrance of the cell to mitosis (SUZUKI \& MATSUBARA, 2011). Thus, p53, when functional, exhibits protective cellular behavior, preventing abnormalities from being transmitted further.

In our study, five tissues presented no expression of TP53 and one tissue presented TP53 underexpression, respectively. As previously described, WOLF \& ROTTER already reported, back in 1984, that the gene encoding p53 in mice was inactivated by retroviral insertion into a cell line transformed into Abelson's murine leukemia. Likewise, COLLAVIN et al., in 2010, also reported that functional loss or unregulated expression of p53 is common in primary tumors and that these 


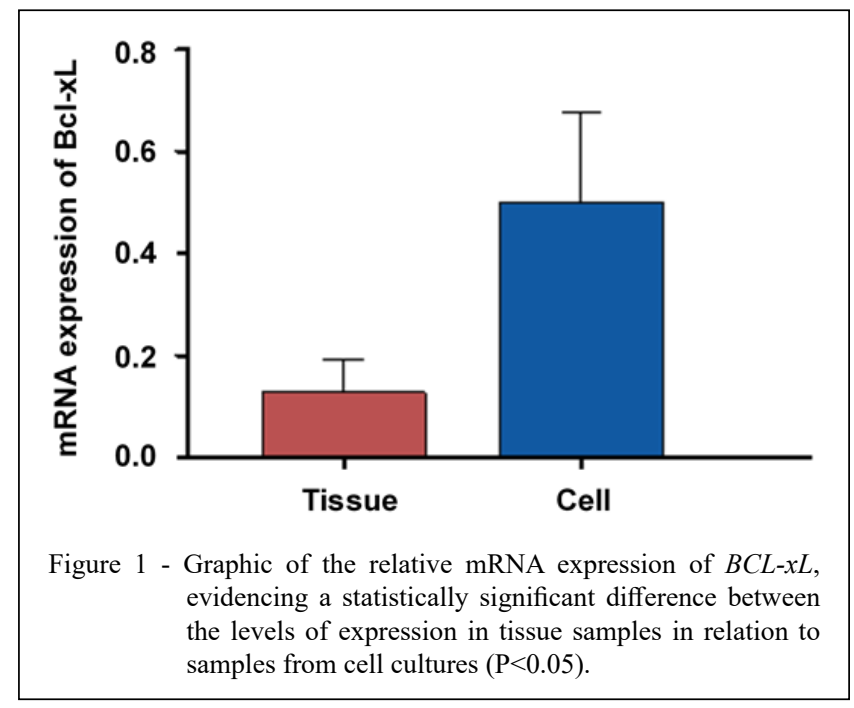

alterations may have a major impact on the regulatory effect common to proteins in the p53 family.

Conversely, our data differed from MORO et al. (2010) that identified a greater amount of p53 protein expression in CTVTs in the regression phase, describing a direct relationship between TP53 and the apoptotic index in CTVTs that are in this phase. Additionally, CHOI \& KIM (2002), SÁNCHEZSERVÍN et al. (2004), and DECKER et al. (2015) also described the presence of mutations of this gene in CTVT. The same animal in which the TP53 expression was low, P21 under expression was also observed. As previously mentioned, TP53 participates in the G1-S phase through p21 transactivation. So $P 21$ expression can be positively regulated by a p53-dependent mechanism, which induces the expression of repair genes in the face of damaged DNA (CHANG et al., 2006). Likewise, the other three samples that also showed decreased P21 expression may also be related to some other signaling mechanism independent of TP53, such as the unregulated presence of $c$-myc or ultraviolet radiation, which leads to negative regulation of $\mathrm{p} 21$ and whose alteration has already been reported in the human cancer cell (WANG et al., 1999), as well as in CTVTs (MURCHISON et al. 2014).

According to KLUMB and JÚNIOR (2002), the mutation in TP53 results in failure to induce $P 21$ gene expression. MØLLER et al. (1999) demonstrated that the expression of p53 associated with the absence of $\mathrm{p} 21$ has $100 \%$ specificity and sensitivity as predictive of mutation in large nonHodgkin's lymphomas. VILLUENDAS et al.
(1997) observed that these same lymphomas, in the presence of mutations of the TP53 gene, had absence or underexpression of p21 and MDM2, suggesting that these mutations are related to the inability to transactivate p21 and MDM2. These researchers proposed that there is a likely alteration in the expression of this gene, which would result in loss of protein function.

Some tissues also presented normalized expression of $P 21$, related to both absence $(18 \%)$ and overexpression (53\%) of TP53. According to SHEIKH et al. (1994) mechanisms that regulate the expression of $P 21$ involve both dependent and independent signaling pathways of TP53. In human ovarian cancer cells, it has been shown that induction of $P 21$ expression can occur through activation of the protein kinase $\mathrm{C}$ in cells lacking p53 (AKASHI et al., 1999), occurring at both transcriptional and posttranscriptional levels (ABBAS \& DUTTA, 2009).

In prostate cells, the expression of $P 21$ can be increased by either the direct action of TP53 (HERNANDEZ et al., 2003) as well as by the action of growth factors (ROBSON et al., 1999). Thus, it is questionable whether this normalized expression of P21 in CTVT is in fact associated with TP53, or is related to some other mechanism of independent signaling of this gene, as an immediate-early response to inducers of cell differentiation, or by the deregulated presence of $c$-myc, which leads to the decoupling of p21 in G1 (STEINMAN et al., 1994), and whose alteration has already been demonstrated in this tumor (COI et al., 2002; LIAO et al., 2003).

The $B A X, B C L-2$ and $B C L-X l$ genes belong to the same family, which comprises approximately 25 genes. In the CTVT, there are no reports on the 
expression of $B C L-x L$; however, the expression of the $B C L-2$ protein has been identified. According to STOCKMANN et al. (2011), the overexpression of $B C L-2$ occurs independently of the stage of tumor development. STOCKMANN et al. (2011) still suggested that its overexpression would promote the acquisition of characteristics in the tumor, associated with progression and survival. Likewise, AMARAL et al. (2011) highlighted that CTVTs with a lower degree of aggressiveness has a high apoptotic index, and may even have a better prognosis.

The decrease in $B C L-2$ expression was observed in three samples, as well as the decrease in $B C L-x L$ in thirteen samples. Thus, the results differ from STOCKMANN et al. (2011), who reported an increase in this protein in CTVT. These authors argued that the increase of $B C L-2$ may be associated with the survival of tumor cells, which causes cell selection to acquire functions associated with tumor progression. WOLF \& ROTTER, (1984) mentioned that there may still be interactions between the family of proteins Bcl-2 and $\mathrm{p} 53$.

In breast cancers, TP53 has the ability to sub-regulate $B C L-2$. Likewise, in ovarian cancers, the expression of $B C L-2$ is inversely related to the expression of TP53 (BASU \& HALDAR, 1998). KUMARAGURUPARAN et al. (2006), on the other hand, observed an increase in $B C L-2$ related to an increase in TP53 in breast tumors. In the present study, there was an increase in TP53, but with no significant alterations for $B C L-2$. Divergences in the expression of $B C L-2$ and TP53 have been described in other studies (BASU \& HALDAR, 1998).

With regard to $B C L-x L$, increased expression of it has already been reported in some types of cancers (GOBÉ et al., 2002; FESIK, 2005). LEITER et al. (2000) observed increased expression of this gene in melanoma metastases, indicating that the expression of $B C L-x L$, as well as $B C L-2$, increases with the progression of the neoplasia. Thus, $B C L-x L$ could reflect an increase in the potential for malignancy, caused by the inhibition of apoptosis, resulting in growth advantages for melanoma cells. Likewise, in pancreatic cancers, their increased expression was associated with shorter patient survival (FRIESS et al., 1998).

However, the same situation was not observed in the present study. In the present study the decrease in $B C L-2$ expression, as well as $B C L$ $x L$, was observed in $18 \%$ and $76 \%$ of the samples, respectively, suggesting that intrinsic apoptosis is not occurring in the tumor microenvironment (Figure 2). This fact may be occurring due to a possible non-functional increase in p53 as, despite its high expression, this does not necessarily indicate that this protein is being translated. Conversely, the expression levels of $B C L-x L$ in tissue samples presented, for the most part, lower values than in samples from cell cultures, so that the tumor microenvironment and its components present in the tissue samples are possibly influencing the levels of pro and antiapoptotic regulation in these cases.

Another apoptotic pathway stimulated by TP53 is that of BAX (CZABOTAR et al., 2014; LACROIX et al., 2006). In the tissues, $41 \%$ presented high expression, and the others $29 \%$ presented normal expression, while $41 \%$ did not express the gene. The expressions of the cells in culture were all normal. In the research, high expression of this gene was expected in all tissues that showed high expression of TP53, since the latter promotes apoptosis through positive regulation of $B A X$, as well as, negative regulation of $B C L-2$ (LIU et al., 2008).

However, this condition was reported in only $41 \%$ of the tissues. Thus, evidence on the possibility of alterations and/or mutations of TP53 in CTVT intensifies, since the loss of TP53 activity in cancer cells has been associated with limitation of the transcriptional activation of $B A X$ and in the consequent activation of apoptosis via the mitochondrial pathway (BASU \& HALDAR, 1998).

According to CZABOTAR et al. (2014) the loss of pro-apoptotic members, such as Bax, accelerates tumor development, as the blockade of apoptosis presumably promotes tumorigenesis by maintaining cell survival. In addition, the overexpression of $B A X$ does not necessarily indicate that this molecule is being translated and functioning properly. Thus, it is necessary to investigate the mechanisms responsible for the survival of this tumor in the host, among them apoptosis, due mainly to the fact that CTVT is not normally the cause of death of the animal and presents a stable nature compared with other types of cancer.

Considering our results, where we observed both absences and underexpressions related to this gene, we questioned the possibility of genetic and/ or epigenetic alterations in CTVT, especially in the tissue samples, in which there was a greater amount of absence of expression in relation to the cells.

Reports on gene mutations in CTVT have already been described. MURGIA et al. (2006) and FONSECA et al. (2012) described the presence of the specific LINE-1/c-myc rearrangement in CTVTs from different countries, while MURCHISON et al. (2014) identified a genetic marker in the 


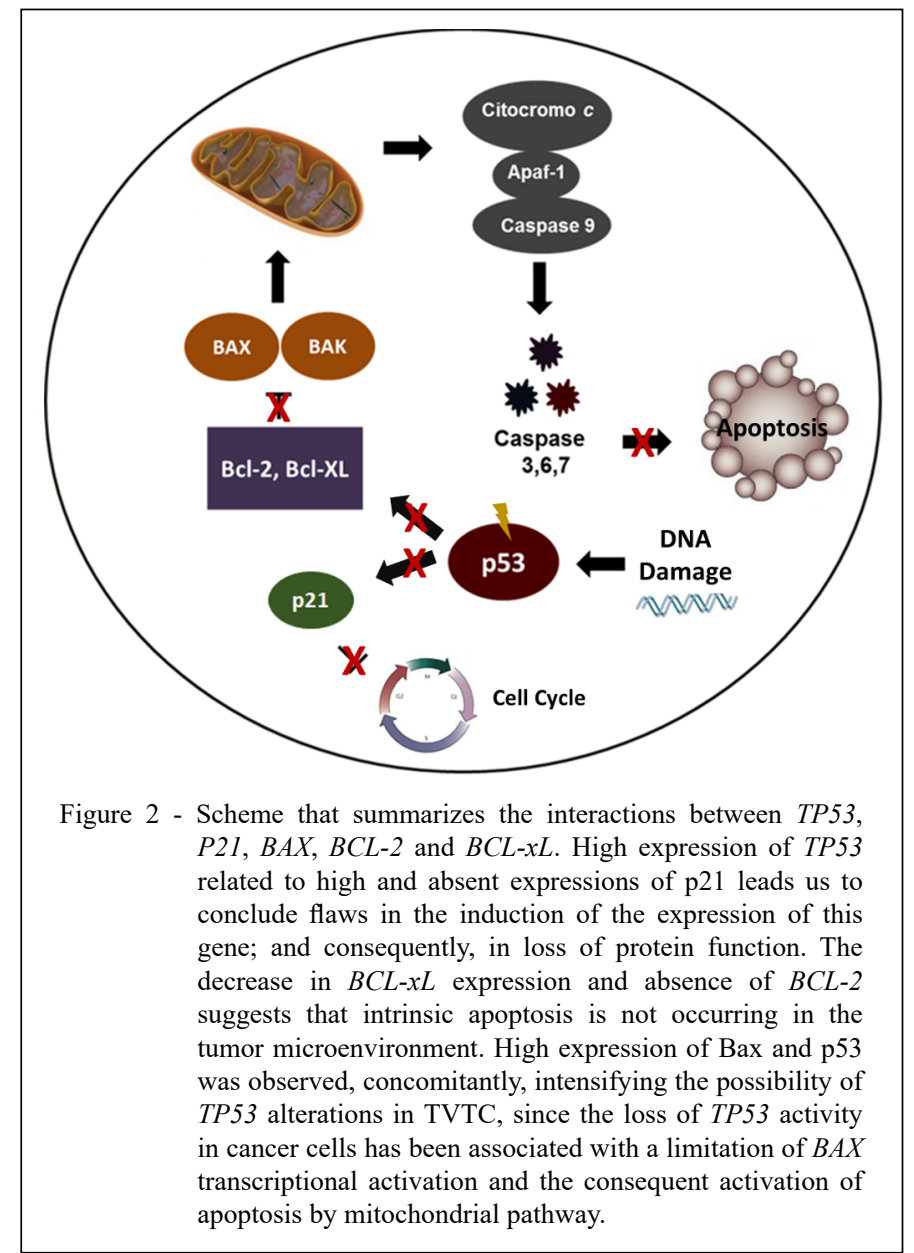

transmission cycle, with approximately $40 \%$ of all mutations being caused by exposure to solar ultraviolet light.

Thus, the understanding and characterization of different carcinogenic types has the potential to open new areas of research to increase knowledge about the biology of these cells, as well as studies on gene expression, mutations, and epigenetic alterations.

\section{CONCLUSION}

The overexpression of TP53 is evident in the majority of tissues and cells, as well as the variability of the expression of genes $P 21, B C L-2$, $B C L-x L$, and $B A X$, possibly occurring due to the presence of genetic and/or epigenetic alterations in CTVT, leading to loss of function in these genes and contributing to the development of tumors through the inactivation of their inhibitory function.

\section{ACKNOWLEDGEMENTS}

This work was financed in part by the Coordenação de Aperfeiçoamento de Pessoal de Nível Superior (CAPES), Brasil, by the Conselho Nacional de Desenvolvimento Científico e Tecnológico (CNPq 445250/2014-3), Brasil and by the Fundação de Amparo à Pesquisa do Estado de São Paulo (FAPESP 2012/19285-2).

\section{BIOETHICS COMMITTEE APPROVAL}

This study was approved by the Ethics Committee on the Use of Animals (CEUA) of the Faculty of Veterinary Medicine and Animal Science: Protocol n ${ }^{\circ} 81 / 2014$.

\section{DECLARATION OF CONFLICTS OF INTERESTS}

The authors declare no conflict of interest. The funding sponsors had no role in the design of the study; in the collection, analyses, or interpretation of data; in the writing of the manuscript, and in the decision to publish the results. 


\section{AUTHORS' CONTRIBUTIONS}

JPAJ and NSR conceived and designed experiments APD supervised and coordinated the animal experiments and provided clinical data. HBF and LMMF performed the experiments and prepared the draft of the manuscript. RSY carried out the lab analyses. RAO performed statistical analyses of experimental data. All authors critically revised the manuscript and approved of the final version.

\section{REFERENCES}

ABBAS, T.; DUTTA, A. p21 in cancer: intricate networks and multiple activities. Nature Reviews Cancer, v.9, n.6, p.400414, 2009. Available from: <http://dx.doi.org/10.1038/nrc2657>. Accessed: Aug. 09, 2019. doi: 10.1038/nrc2657.

AKASHI, M., et al. p21 $1^{\text {WAF1 }}$ expression by an activator of protein kinase $\mathrm{C}$ is regulated mainly at the post-transcriptional level in cells lacking p53: important role of RNA stabilization. Biochemical Journal, v.337, p.607-616, 1999. Available from: <https:// europepmc.org/article/med/9895308>. Accessed: Aug. 06, 2019. doi:10.1042/0264-6021:3370607.

ALZATE, J.M., et al. The role of the multi-drug resistance 1, p53, b cell lymphoma 2, and bcl 2-associated $\mathrm{X}$ genes in the biologic behavior and chemotherapeutic resistance of canine transmissible venereal tumors. Veterinary Clinical Pathology, v.48, n.4, p.730739, 2009. Available from: <http://dx.doi.org/10.1111/vcp.12805>. Accessed: Apr.18, 2020. doi: 10.1111/vcp.12805.

AMARAL, A.S., et al. DNA damage in canine transmissible venereal tumor cells. Revista Lusófona de Ciência e Medicina Veterinária, v.4, p.1-5, 2011. Available from: <https://revistas. ulusofona.pt/index.php/rlcmv/article/view/2388>. Accessed: Sep. $11,2019$.

BASU, A.; HALDAR, S. The relationship between Bcl-2, Bax and p53: consequences for cell cycle progression and cell death. Molecular Human Reproduction, v.4, n.12, p.1099-1109, 1998. Available from: <http://dx.doi.org/10.1093/molehr/4.12.1099>. Accessed: Sep. 11, 2019. doi: 10.1093/molehr/4.12.1099.

BELOV, K. Contagious câncer: Lessons from the devil and the dog. Bioessays, v.34, n.4, p.285-292, 2012. Available from: $<$ https://pubmed.ncbi.nlm.nih.gov/22383221>. Accessed: Dec. 11, 2019. doi: 10.1002/bies.201100161.

BOSCOS, C.M., et al. Cutaneous involvement of TVT in dogs: a report of two cases. Canine Practice, v.24, n.4, p.6-11, 1999. Available from: <http://agris.fao.org/agris-search/search. do?recordID=US201302939542>. Accessed: Aug. 09, 2019.

BRINKHOF, B., et al. Development and evaluation of canine reference genes for accurate quantification of gene expression. Analytical Biochemistry, v.356, p.36-43, 2006. Available from: $<$ https://pubmed.ncbi.nlm.nih.gov/16844072>. Accessed: Aug. 09 2019. doi: 10.1016/j.ab.2006.06.001.

CHANG, H.W., et al. Expression of Ku80 correlates with sensitivities to radiation in cancer cell lines of the head and neck. Oral Oncology, v.42, n.10, p.979-986, 2006. Available from: $\quad<$ http://dx.doi.org/10.1016/j.oraloncology.2005.12.016>. Accessed: Mar. 30, 2020. doi:10.1016/j.oraloncology.2005.12.016.
CHOI, Y.K. \& KIM, C.J. Sequence analysis of canine LINE-1 elements and p53 gene in canine transmissible venereal tumor. Journal of Veterinary Science, v.3, n.4, p.285-292, 2002. Available from: <http://dx.doi.org/10.4142/jvs.2002.3.4.285>. Accessed: Sep. 11, 2019. doi: 10.4142/jvs.2002.3.4.285.

COLLAVIN, L., et al. p53-family proteins and their regulators: hubs and spokes in tumor suppression. Cell Death \& Differentiation, v.17, n.6, p.901-911, 2010. Available from: <http://dx.doi. org/10.1038/cdd.2010.35>. Accessed: Dec. 11, 2019. doi: 10.1038/ cdd.2010.35.

CZABOTAR, P.E., et al. Control of apoptosis by the BCL-2 protein family: implications for physiology and therapy. Nature Reviews Molecular Cell Biology, v.15, p.49-63, 2014. Available from: $<$ http://dx.doi.org/10.1038/nrm3722>. Accessed: Oct. 03, 2019. doi: $10.1038 / \mathrm{nrm} 3722$.

DECKER, B., et al. Comparison against 186 canid whole-genome sequences reveals survival strategies of an ancient clonally transmissible canine tumor. Genome Research, v.25, n.11, p.1646-1655, 2015. Available from: $<$ http://dx.doi.org/10.1101/ gr.190314.115> Accessed: Sep. 15, 2019. doi: 10.1101/ gr.190314.115.

DOHOO, I., et al. Veterinary Epidemiologic Research. $2^{\text {nd }}$ ed. VER Inc: Canadá. 2009. 865 p.

DUZANSKI, A.P., et al. Canine transmissible venereal tumor: is its biological behavior changing? The Anatomical Record, v.300, n.6, p.1009-1010, 2017. Available from: <http://dx.doi. org/10.1002/ar.23527>. Accessed: Sep. 15, 2019. doi: 10.1002/ ar.23527.

FESIK, S.W. Promoting apoptosis as a strategy for cancer drug discovery. Nature reviews. Cancer, v.5, n.11, p.876-885, 2005. Available from: <http://dx.doi.org/ 10.1038/nrc1736>. Accessed: Mar. 30, 2020. doi: 10.1038/nrc1736.

FLÓREZ, M.M., et al. Cell cycle kinetics, apoptosis rates and gene expressions of $M D R-1, T P 53, B C L-2$ and $B A X$ in transmissible venereal tumour cells and their association with therapy response. Veterinary and Comparative Oncology, v.15, n.3, p.793-807, 2017. Available from: <http://dx.doi.org/10.1111/vco.12220>. Accessed: Apr. 18, 2020. doi: 10.1111/vco.12220.

FLÓREZ, L.M.M., et al. Immunocytochemical characterization of primary cell culture in canine transmissible venereal tumor. Pesquisa Veterinária Brasileira, v.36, n.9, p.844850, 2016. Available from: <http://dx.doi.org/10.1590/S0100736X2016000900009>. Accessed: Oct. 03, 2019. doi: 10.1590/ S0100-736X2016000900009.

FONSECA, L.S., et al. Spontaneous canine transmissible venereal tumor: association between different phenotypes and the insertion LINE-1/c-myc. Revista Colombiana de Ciencias Pecuarias, v.25, p.402-408, 2012. Available from: <http://www.scielo.org.co/ scielo.php?script $=$ sci_arttext\&pid $=$ S0120-06902012000300007 $>$. Accessed: Aug. 09, 2019.

FRIESS, H., et al. Moderate activation of the apoptosis inhibitor bcl-xL worsens the prognosis in pancreatic cancer. Annals of Surgery, v.228, n.6, p.780-787, 1998. Available from: <http:// dx.doi.org/10.1097/00000658-199812000-00009>. Accessed: Mar. 31, 2020. doi: 10.1097/00000658-199812000-00009.

Ciência Rural, v.50, n.11, 2020. 
GASPAR, L.F., et al. Spontaneus canine transmissible venereal tumor: cell morphology and influence on p-glycoprotein expression. The Turkish Journal of Veterinary and Animal Sciences, v.34, p-447-454, 2010. Available from: <http://journals. tubitak.gov.tr/veterinary/issues/vet-10-34-5/vet-34-5-5-0911-198. pdf $>$. Accessed: Apr. 04, 2020. doi: 10.3906/vet-0911-198.

GOBÉ, G., et al. Apoptosis and expression of Bcl-2, Bcl-X , $_{\text {, and }}$ Bax in renal cell carcinomas. Cancer Investigation, v.20, n.3, p.324-332, 2002. Available from: <http://dx.doi.org/10.1081/ cnv-120001177>. Accessed: Mar. 30, 2020. doi: 10.1081/cnv120001177.

HERNANDEZ, I., et al. Prostate-specific expression of p53(R172L) differentially regulates $\mathrm{p} 21$, Bax, and $\mathrm{mdm} 2$ to inhibit prostate cancer progression and prolong survival. Molecular Cancer Research, v.1, n.14, p.1036-1047, 2003. Available from: $<$ https://www.ncbi.nlm.nih.gov/pubmed/14707287>. Accessed: Sep. 15, 2019

HSIAO, Y., et al. Interactions of host IL- 6 and IFN- $\gamma$ and cancerderived TGF- $\beta 1$ on MHC molecule expression during tumor spontaneous regression. Cancer Immunology, Immunotherapy, v.57, p.1091-1104, 2008. Available from: <http://dx.doi. org/10.1007/s00262-007-0446-5>. Accessed: Sep. 11, 2019. doi: $10.1007 / \mathrm{s} 00262-007-0446-5$.

KUMARAGURUPARAN, R., et al. Of humans and canines Immunohistochemical analysis of PCNA, Bcl-2, p53, cytokeratin and ER in mammary tumours. Research in Veterinary Science, v.81, n.2, p.218-224, 2006. Available from: $<$ http://dx.doi. org/10.1016/j.rvsc.2005.08.002>. Accessed: Mar. 30, 2020. doi: 10.1016/j.rvsc.2005.08.002.

KLUMB, C.E.; JÚNIOR, G.B.C. Avaliação dos métodos de detecção das alterações do gene e proteína P53 nas neoplasias linfoides. Revista Brasileira de Hematologia e Hemoterapia, v.24, n.2, p.111-125, 2002. Available from: <http://dx.doi. org/10.1590/S1516-84842002000200008>. Accessed: Aug. 09, 2019. doi: 10.1590/S1516-84842002000200008.

KLOPFLEISCH, R.; GRUBER, A.D. Differential expression of cell cycle regulators p21, p27 and p53 in metastasizing canine mammary adenocarcinomas versus normal mammary glands. Research in Veterinary Science, v.87, p.91-96, 2009. Available from: <http://dx.doi.org/10.1016/j.rvsc.2008.12.010>. Accessed: Aug. 09, 2019. doi: 1010.1016/j.rvsc.2008.12.010.

KLOPFLEISCH, R., et al. The combined expression pattern of $B M P 2, L T B P 4$, and $D E R L 1$ discriminates malignant from benign canine mammary tumors. Veterinary Pathology, v.47, n.3, p.446-454, 2010. Available from: <http://dx.doi org/10.1177/0300985810363904>. Accessed: Aug. 09, 2019. doi: $10.1177 / 0300985810363904$.

KUSEWITT, D.F. Neoplasia and Tumor Biology. In: ZACHARY, J.F. \& McGAVIN, M.D. Pathologic Basis of Veterinary Disease. $5^{\text {nd }}$ ed. Rio de Janeiro: Elsevier, 2013.

LACROIX, M., et al. p53 and breast cancer, an update. Endocrine Related Cancer, v.13, n.2, p.293-325, 2006. Available from: $<$ http://dx.doi.org/10.1677/erc.1.01172>. Accessed: Aug. 09, 2019, 2019. doi: 10.1677/erc.1.01172.

LARIONOV, A., et al. A standard curve based method for relative real time PCR data processing. BMC Bioinformatics, v.6, n.62, p.1-16, 2005. Available from: <http://dx.doi.org/10.1186/14712105-6-62>. Accessed: Aug. 06, 2019. doi: 10.1186/1471-21056-62.

LEE, C.H., et al. Mutation and overexpression of $p 53$ as a prognostic factor in canine mammary tumors. Journal of Veterinary Science, v.5, p.63-69, 2004. Available from: <http:// dx.doi.org/10.4142/jvs.2004.5.1.63>. Accessed: Mar. 30, 2020. doi:10.4142/jvs.2004.5.1.63.

LEITER, U. et al. Antiapoptotic bcl-2 and bcl-xL in advanced malignant melanoma. Archives of Dermatological Research, v.292, p.225-232, 2000. Available from: <http://dx.doi. org/10.1007/s004030050479>. Accessed: Mar. 30, 2020. doi: $10.1007 / \mathrm{s} 004030050479$.

LIAO, K.W., et al. Identification of canine transmissible venereal tumor cells using in situ polymerase chain reaction and the stable sequence of the long interspersed nuclear element. Journal of Veterinary Diagnostic Investigation, v.15, n.5, p.399-406, 2003. Available from: <http://dx.doi.org/10.1177/104063870301500501 >. Accessed: Oct. 03, 2019. doi: 10.1177/104063870301500501.

LIU, F.S., et al. Expression analysis of apoptosis-related markers TP53, BCL-2, BAX and c-MYC in female genital tract sarcomas. Journal of the Chinese Medical Association, v.71, n.12, p.628634, 2008. Available from: <http://dx.doi.org/ 10.1016/S17264901(09)70005-X>. Accessed: Oct. 03, 2019. doi: 10.1016/S17264901(09)70005-X.

MORO, J.V., et al. Reactivity of $\mathrm{p} 53$ protein in canine transmissible venereal tumor. Arquivo Brasileiro de Medicina Veterinária e Zootecnia, v.62, n.2, p.318-323, 2010. Available from: <http:// dx.doi.org/10.1590/S0102-09352010000200011>. Accessed: Mar. 30, 2020. doi: 10.1590/S0102-09352010000200011.

MØLLER, M.B., et al. Disrupted p53 function as predictor of treatment failure and poor prognosis in B cell non-Hodgkin's lymphoma. Clinical Cancer Research, v.5, n.5, p.10851091, 1999. Available from: <https://pubmed.ncbi.nlm.nih. gov/10353742>. Accessed: Sep. 11, 2019.

MUKARATIRWA, S.; GRUYS, E. Canine transmissible venereal tumour: cytogenetic origin, immunophenotype, and immunobiology. A review. Veterinary Quarterly, v.25, n.3, p.101-111, 2003. Available from: <http://dx.doi.org/10.108 0/01652176.1997.9694744>. Accessed: Oct. 03, 2019. doi: 10.1080/01652176.1997.9694744.

MURCHISON, E.P., et al. Transmissable dog cancer genome reveals the origin and history of an ancient cell lineage. Science, v.343, n.6169, p.437-440, 2014. Available from: <http://dx.doi. org/10.1126/science.1247167>. Accessed: Oct. 03, 2019. doi: 10.1126/science. 1247167 .

MURGIA, C., et al. Clonal origin and evolution of a transmissible cancer. Cell, v.126, n.3, p.477-487, 2006. Available from: <http:// dx.doi.org/10.1016/j.cell.2006.05.051>. Accessed: Sep. 11, 2019. doi: $10.1016 /$ j.cell.2006.05.051.

VÁZQUEZ-MOTA, N., et al. The T963C mutation of TP53 gene does not participate in the clonal origin of canine TVT. Veterinary Research Communications. v.32, n.2, p.187-191, 2008. Available from: <http://dx.doi.org/10.1007/s11259-007-9013-y>. Accessed: Oct. 03, 2019. doi: 10.1007/s11259-007-9013-y. 
OJEDA, J., et al. Computer tomograohic imaging in 4 dogs with primary nasal canine venereal tumor and differing cellular phenotype. Journal of Veterinary Internal Medicine, v.32, n.3, p.1172-1177, 2018. Available from: <http://dx.doi.org/10.1111/ jvim.15125>. Accessed: Aug. 09, 2019. doi: 10.1111/jvim.15125.

ROBSON, C.N., et al. Transforming growth factor-betal upregulates p15, p21 and p27 and blocks cell cycling in G1 in human prostate epithelium. Journal of Endocrinology, v.160, n.2, p.257-266, 1999. Available from: < http://dx.doi.org/10.1677/ joe.0.1600257>. Accessed: Aug. 06, 2019. doi: 10.1677/ joe. 0.1600257

SÁNCHEZ-SERVÍN, A., et al. TP53 polymorphisms allow for genetic sub-grouping of the canine transmissible venereal tumor Journal of Veterinary Science, v.10, n.4, p.353-355, 2009. Available from: <http://dx.doi.org/10.4142/jvs.2009.10.4.353>. Accessed: Aug. 09, 2019. doi: 10.4142/jvs.2009.10.4.353.

SANO, J., et al. High expression of Bcl-xL in delayed apoptosis of canine neutrophils induced by lipopolysaccharide. Research in Veterinary Science, v.78, p.183-187, 2005. Available from: $<$ http://dx.doi.org/10.1016/j.rvsc.2004.07.008>. Accessed: Aug. 09, 2019. doi: 10.1016/j.rvsc.2004.07.008.

SANTOS, F.G.A., et al. The canine Transmissible Venereal Tumor - General Aspects and Molecular Approach (Review). Bioscience Journal, v.21, p.41-53, 2005. Available from:<https:// www.researchgate.net/publication/277212810_O_tumor venereo_transmissivel_canino_-aspectos_gerais_e_abordagens_ moleculares_Revisao_de_literatura $>$.Accessed: Sep. 11, 2019.

SHEIKH, M.S., et al. Mechanisms of regulation of WAF1/Cip1 gene expression in human breast carcinoma: role of p53-dependent and independent signal transduction pathways. Oncogene, v.9 n.12, p.3407-3415, 1994. Available from: <https://www.ncbi.nlm. nih.gov/pubmed/7970699>. Accessed: Aug. 09, 2019.

STEINMAN, R.A., et al. Induction of p21 (WAF-1/CIP1) during differentiation. Oncogene. v.9, n.11, p.3389-3396, 1994. Available from: $<$ https://www.ncbi.nlm.nih.gov/pubmed/7936667>. Accessed: Aug. 06, 2019.

STOCKMANN, D., et al. Canine transmissible venereal tumours: aspects related to programmed cell death. Brazilian Journal of Veterinary Pathology, v.4, p.67-75, 2011. Available from:
$<$ https://bjvp.org.br/wp-content/uploads/2015/07/DOWNLOADFULL-ARTICLE-13-20881 201131621 6.pdf>. Accessed: Sep. 15, 2019.

SUI, X., et al. p53 signaling and autophagy in cancer: A revolutionary strategy could be developed for cancer treatment. Autophagy, v.7, n.6, p.565-571, 2011. Available from: <http:// dx.doi.org/10.4161/auto.7.6.14073>. Accessed: Oct. 03, 2019. doi: 10.4161/auto.7.6.14073

SUZUKI, K. \& MATSUBARA H. Recent advances in p53 research and cancer treatment. Journal of Biomedicine and Biotechnology, 2011. Available from: <http://dx.doi.org/10.1155/2011/978312>. Accessed: Oct. 03, 2019. doi: 10.1155/2011/978312.

TINUCCI-COSTA M. Tumor Venéreo Transmissível. In: DALECK, C.R. \& NARDI, A.B. Oncologia em cães e gatos. $2^{\text {nd }}$ ed. Roca: Rio de Janeiro. 2009.

VELDHOEN, N., et al. Mutations of the p53 gene in canine lymphoma and evidence for germ line p53 mutations in the dog. Oncogene, v.16, n.2, p.249-255, 1998. Available from: <http:// dx.doi.org/10.1038/sj.onc.1201489>. Accessed: Mar. 30, 2020. doi:10.1038/sj.onc. 1201489 .

VILLUENDAS, R., et al. p2 $1^{\mathrm{WAF} 1 / \mathrm{CIP} 1}$ and MDM2 expression in non-Hodgkin's lymphoma and their relationship to p53 status: A p53+, MDM2-, p21- immunophenotype associated with missense p53 mutations. The Journal of Pathology, v.181, p.51-61, 1997. Available from: <http://dx.doi.org/10.1002/(SICI)10969896(199701) 181:1<51::AID-PATH689>3.0.CO;2-N $>$. Accessed: Aug. 09, 2019. doi: 10.1002/(SICI)10969896(199701)181:1<51::AID-PATH689>3.0.CO;2-N.

WANG, J.A, et al. Ultraviolet radiation down-regulates expression of the cell-cycle inhibitor $\mathrm{p} 21^{\mathrm{WAF} 1 / \mathrm{CIP} 1}$ in human cancer cells independently of p53. International Journal of Radiation Biology, v.75, n.3, p.301-316, 1999. Available from: <http:// dx.doi.org/10.1080/095530099140483>. Accessed: Jun. 26, 2020. doi: $10.1080 / 095530099140483$.

WOLF, D.; ROTTER, V. Inactivation of p53 gene expression by an insertion of Moloney murine leukemia virus-like DNA sequences. Molecular and Cellular Biology, v.4, n.7, p.1402-1410, 1984. Available from: <http://dx.doi.org/10.1128/mcb.4.7.1402>. Accessed: Oct. 03, 2019. doi: 10.1128/mcb.4.7.1402. 